\title{
Effects of granulocyte colony-stimulating factor administration time on pain
}

\author{
Ozkaraman $\mathrm{A}^{1}$, Argon $\mathrm{G}^{2}$, Usta Yesilbalkan $\mathrm{O}^{2}$, Dugum $\mathrm{O}^{3}$, Yigitaslan $\mathrm{S}^{4}$, Musmul $\mathrm{A}^{5}$, \\ Balci Alparslan $\mathrm{G}^{1}$
}

Eskisehir Osmangazi University, Faculty of Health Sciences, Department of Nursing, Eskisehir, Turkey. aozaydin26@hotmail.com

\begin{abstract}
OBJECTIVE: This study was aimed at evaluating the effect of administration time of granulocyte colony-stimulating factor (G-CSF) on the level of pain related to G-CSF.

METHODS: This study was carried out with 48 cancer patients divided into A and B groups. In the first stage of the study, the groups A and B were planned to be administered with G-CSF at 10: 00 and 14: 00, respectively. In the second stage, patients in groups A and B were asked to self-administer filgrastim at 14: 00 and 10: 00, respectively. Patients were also asked to assess their pain level after G-CSF administration for a total of 4 times. RESULTS: According to the findings, the incidence of pain related to G-CSF was $91.7 \%$. The pain score after G-CSF being administered at 10: 00 was significantly higher compared to administration at 14: 00 in both groups (group A after 4, 8, and 12 hours: $p<0.05$; group B after 4 and 8 hours: $p<0.05$ ).

CONCLUSIONS: The results of the present study have demonstrated that the pain score related to G-CSF administration at 14:00 p.m. was significantly reduced. Thus, in order to minimize the pain, it will be more beneficial to administer G-CSF at 14: 00 (Tab. 4, Ref. 31). Text in PDF www.elis.sk.

KEY WORDS: cancer, G-CSF, pain, nurse.
\end{abstract}

\section{Introduction}

Neutropenia is a commonly seen serious adverse effect of cancer treatment $(1,2,3)$. The incidence of neutropenia decreases by $50 \%$ with the use of granulocyte colony-stimulating factor (G-CSF) $(4,5)$. The most commonly used G-CSF preparations in Turkey and worldwide are filgrastim and lenograstim (6). Patients may experience adverse effects including headache, bone pain, myalgia and arthralgia related to G-CSF which are usually managed using pharmacological agents $(3,7-11)$.

Pain management varies, and is complex because of individual differences and circadian pain behavior $(12,13)$. It has been suggested that pain varies with individuals and different diseases, and because the circadian rhythm influences the pharmacodynamic and pharmacokinetic properties of the drugs, pain management should be conservative and individualized (12). In a study on circadian changes during a $24-\mathrm{h}$ period induced by CFU-GM in bone marrow, the production of myeloid progenitor cells has been reported

${ }^{1}$ Eskisehir Osmangazi University, Faculty of Health Sciences, Department of Nursing, Eskisehir, Turkey, ${ }^{2}$ Ege University, Faculty of Nursing, İzmir, Turkey, ${ }^{3}$ Eskisehir Special Ümit Batıkent Hospital, Eskisehir, Turkey, ${ }^{4}$ Eskisehir Osmangazi University, Faculty of Medicine, Department of Pharmacology, Eskisehir, Turkey, and ${ }^{5}$ Eskisehir Osmangazi University, Faculty of Medicine, Department of Biostatistics, Eskisehir, Turkey

Address for correspondence: A. Özkaraman, RN, PhD, Eskisehir Osmangazi University Faculty of Health Sciences, Department of Nursing, Meselik Campus, Odunpazarı, Eskisehir, Turkey. Postal code: 26480. Phone: $+90.222 .2393750-1526$ to start to increase at 04.00 , peak at $12.00 \mathrm{p} . \mathrm{m}$. and start to decrease at 16.00 p.m. (14). During the 24-h circadian rhythm of bone marrow, the percentage of bone marrow cells at the DNA synthesis phase is $188 \%$ higher in the midday compared to midnight with a similar circadian change seen in granulocyte/macrophages during the DNA synthesis phase (15).

Although there are several previous studies investigating the relationship between the circadian rhythm and proliferation of bone marrow cells or pain $(12,14,15)$, to the best of our knowledge, no studies have investgated the circadian rhythm in pain induced by G-CSF treatment used to induce neutrophile proliferation. This semi-experimental study was planned in order to investigate the influence of administration time of G-CSF on myalgia and arthralgia induced by the drug used to prevent neutropenia in cancer patients.

\section{Material and methods}

\section{Study design}

This semi-experimental, self-controlled study was conducted in order to investigate the effect of administration time of filgrastim on myalgia and arthralgia induced by filgrastim used to prevent neutropenia in cancer patients.

\section{Study setting and population}

The study was carried out at the chemotherapy unit of hospital at Eskisehir between November 31, 2014 and July 31, 2015.

Study population consisted of patients who had received GCSF treatment the day after chemotherapy. The study sample con- 
sisted of patients meeting inclusion criteria and agreeing to participate in the study. Study sample excluded the patients who reported to have used analgesic medication during filgrastim application.

Inclusion criteria:

- Being literate,

- Having no mental or communication problems,

- Being over 18 years and under 74 years of age,

- Having ability to self-administer subcutaneous 30 MIU G-CSF (filgrastim)

- Agreeing to participate in the study.

The repeated measures of Anova statistical power analysis was conducted in order to determine the adequacy of sample size. In the statistical power analysis based on Quantitative Pain Assessment Scale value, the number of units for each group was determined as 7 for the effect power of $0.99 \%$ with a $\alpha$ value of 0.05 , and $\beta$ value of 0.0033 .

\section{Outcome measures}

Data were collected through observation, face-to-face- interview and measurement methods, and by using Patient Identification Form and Quantitative Pain Assessment Scale.

Patient Identification Form: The form prepared by the researchers consists of 16 items regarding sociodemographic features and disease- and treatment-related factors $(16,17)$.

Quantitative Pain Assessment Scale (QPAS): This scale assessing the pain severity aims to quantify the pain of patient. The scores of the scale range from 0 to 10 with 0 indicating no pain and 10 indicating intolerable pain severity (18).

\section{Data collection procedure}

The patients who met the inclusion criteria were systematically assigned into two groups (A and B) by using a simple randomization method. First and second stages of the study were carried out in both groups of patients.

First stage: The filgrastim treatment was planned to be selfadministered the day after chemotherapy by the patient according to the decision of physician who instructed the administration to be carried out at 10:00 in group A and at 14: 00 in group B. Patients were also asked to assess their pain level by using Quantitative Pain Assessment Scale every four hours after the drug administration for a total of 4 times (Tab. 1).

Second stage: In this stage, patients in group A and B were asked to self-administer filgrastim at 14: 00 p.m. and 10: 00, respectively. Again, patients were instructed to assess their pain level by using Quantitative Pain Assessment Scale every four hours after the drug administration for a total of 4 times (Tab. 1). Because the drugs in our country are most commonly administered at 10:00 and 14: 00, filgrastim was instructed to be administered at these particular points of time.

\section{Data analysis}

All data were analyzed by using SPSS 21.0 package program (19). Continuous quantitative data are given as n, mean and standard error while qualitative data are given as n, median, 25 th and
Tab. 1. A schematic view of study.

\begin{tabular}{|c|c|c|}
\hline \multicolumn{3}{|c|}{ Assessment of patients according to inclusion criteria } \\
\hline Patients meeting & the criteria $(n=48)$ & $\begin{array}{c}\downarrow \\
\text { Patients not meeting } \\
\text { the criteria }(\mathrm{n}=10) \\
\downarrow\end{array}$ \\
\hline $\begin{array}{c}\text { Randomization of the pa } \\
\downarrow\end{array}$ & $\begin{array}{c}\text { tients into group A and B } \\
\downarrow \downarrow\end{array}$ & $\begin{array}{l}\text { Exclusion from the } \\
\text { study }\end{array}$ \\
\hline Group A $(n=24)$ & Group B $(n=24)$ & \\
\hline First stage: & First stage: & \\
\hline $\begin{array}{l}\text { Patients administered the } \\
\text { first filgrastim at 10:00 }\end{array}$ & $\begin{array}{l}\text { Patients administered } \\
\text { the first filgrastim at 14:00 }\end{array}$ & \\
\hline $\begin{array}{l}\text { Patients assessed their } \\
\text { pain level at } 10.00,14: 00 \text {, } \\
18: 00 \text { and } 22: 00\end{array}$ & $\begin{array}{l}\text { Patients assessed their } \\
\text { pain level at 14:00, 18:00, } \\
22: 00 \text { and } 02: 00\end{array}$ & \\
\hline $\begin{array}{l}\text { Second stage: Patients } \\
\text { administered the second } \\
\text { filgrastim at } 14: 00 \text {. }\end{array}$ & $\begin{array}{l}\text { Second stage: Patients } \\
\text { administered the second } \\
\text { filgrastim at 10:00 }\end{array}$ & \\
\hline $\begin{array}{l}\text { Patients assessed their } \\
\text { pain level at 14:00, 18:00, } \\
22: 00 \text { and } 02: 00\end{array}$ & $\begin{array}{l}\text { Patients assessed their } \\
\text { pain level at 10:00, 14:00, } \\
18: 00 \text { and } 22: 00\end{array}$ & \\
\hline $\begin{array}{c}\downarrow \\
\text { Data analysis }\end{array}$ & & \\
\hline
\end{tabular}

$75^{\text {th }}$ percentiles. Kruskal-Wallis and Mann-Whitney U tests were used for data series consisting of independent measurements or scoring and Wilcoxon Signed Ranks test was used for dependent variables. The significance level was set at $\mathrm{p}<0.05$.

\section{Ethical considerations}

This study was approved by Ethical Committee of Hospital (approval date/number: November 14, 2014/2014-210). After giving written and verbal information, all study subjects gave written consent. They were informed on the fact that if they wanted to discontinue participation, they could leave the study without stating their reason.

\section{Results}

Socio-demographic and clinical characteristics of the sample

The total of 48 patients with cancer were included in the analysis (22 men and 26 women). During the study period, a total of 15 patients were excluded from the study because 11 patients were reported to have been using analgesic medication regularly, and 4 patients did not complete the study. The mean age of the study population was $56.52 \pm 12.08$ years $(57.66 \pm 11.76$ years in group A and $55.38 \pm 12.54$ years in group B). Of the patients, $54.2 \%$ were female, $45.8 \%$ were male, $41.7 \%$ were secondary school graduates and majority $(89.6 \%)$ were married. Of the patients included in the study, $33.3 \%, 25 \%, 12.5 \%$, and $8.4 \%$ had breast carcinoma, gastrointestinal cancers, lung cancer, hematological cancers, soft tissue cancer, respectively and and $41.7 \%$ were at the second stage of the disease. Chemotherapy-induced neutropenia was seen in $83.3 \%$, while $81.3 \%$ of patients had filgrastim administered previously (mean $2.47 \pm 1.68$ ) (Tab. 2). 
Tab. 2. Sociodemographic characteristics and disease- and treatment-related factors.

\begin{tabular}{|c|c|c|c|c|c|c|}
\hline Informative characteristics & \multicolumn{2}{|c|}{ Group A } & \multicolumn{2}{|c|}{ Group B } & \multicolumn{2}{|c|}{ Total } \\
\hline Age (year) & \multicolumn{2}{|c|}{$57.66 \pm 11.76$} & \multicolumn{2}{|c|}{$55.38 \pm 12.54$} & \multicolumn{2}{|c|}{$56.52 \pm 12.08$} \\
\hline Course & \multicolumn{2}{|c|}{$4.42 \pm 4.95$} & \multicolumn{2}{|c|}{$3.21 \pm 2.17$} & \multicolumn{2}{|c|}{$3.81 \pm 3.82$} \\
\hline Previous G-CSF administrations (number) & \multicolumn{2}{|c|}{$2.12 \pm 1.75$} & \multicolumn{2}{|c|}{$2.83 \pm 1.58$} & \multicolumn{2}{|c|}{$2.47 \pm 1.68$} \\
\hline & $\mathrm{n}$ & $\%$ & $\mathrm{n}$ & $\%$ & $\mathrm{n}$ & $\%$ \\
\hline \multicolumn{7}{|l|}{ Gender } \\
\hline Female & 11 & 22.9 & 15 & 31.3 & 26 & 54.2 \\
\hline Male & 13 & 27.1 & 9 & 18.8 & 22 & 45.8 \\
\hline \multicolumn{7}{|l|}{ Marital status } \\
\hline Married & 22 & 45.8 & 21 & 43.8 & 43 & 89.6 \\
\hline Single & 2 & 4.2 & 3 & 6.3 & 5 & 10.4 \\
\hline \multicolumn{7}{|l|}{ Educational status } \\
\hline Solely literate & 6 & 12.5 & 2 & 4.2 & 8 & 16.7 \\
\hline Primary school & 4 & 8.3 & 4 & 8.3 & 8 & 16.7 \\
\hline Secondary school & 9 & 18.8 & 11 & 22.9 & 20 & 41.7 \\
\hline High school & 5 & 10.4 & 7 & 29.2 & 12 & 25 \\
\hline \multicolumn{7}{|l|}{ Employment } \\
\hline Civil servant & 3 & 6.3 & 4 & 8.3 & 7 & 14.6 \\
\hline Worker & 2 & 4.2 & 1 & 2.1 & 3 & 6.3 \\
\hline Housewife & 11 & 22.9 & 8 & 16.7 & 19 & 39.6 \\
\hline Retired & 8 & 16.7 & 11 & 22.9 & 19 & 39.6 \\
\hline \multicolumn{7}{|l|}{ Diagnosis } \\
\hline $\begin{array}{l}\text { Gastrointestinal cancers (esophageal, } \\
\text { gastric, colon, rectal) }\end{array}$ & 7 & 14.6 & 5 & 10.4 & 2 & 25 \\
\hline Lung cancer & 1 & 2.1 & 5 & 10.4 & 6 & 12.5 \\
\hline Breast cancer & 7 & 14.6 & 9 & 18.8 & 16 & 33.3 \\
\hline Soft tissue cancer & 2 & 4.2 & 2 & 4.2 & 4 & 8.3 \\
\hline Hematological cancers (CLL, NHL) & 4 & 8.4 & 0 & 0 & 4 & 8.4 \\
\hline Prostate cancer & 2 & 4.2 & 1 & 2.1 & 3 & 6.3 \\
\hline Testicular cancer & 0 & 0 & 2 & 4.2 & 2 & 4.2 \\
\hline Ovarian cancer & 1 & 2.1 & 0 & 0 & 1 & 2.1 \\
\hline 2 & 10 & 20.8 & 10 & 20.8 & 20 & 41.7 \\
\hline 3 & 5 & 10.4 & 5 & 10.4 & 10 & 20.8 \\
\hline 4 & 4 & 8.3 & 2 & 4.2 & 6 & 12.5 \\
\hline \multicolumn{7}{|l|}{ Previous neutropenia } \\
\hline Yes & 17 & 35.4 & 23 & 47.9 & 40 & 83.3 \\
\hline No & 7 & 14.6 & 1 & 2.1 & 8 & 16.7 \\
\hline \multicolumn{7}{|l|}{ Previous use of G-CSF } \\
\hline Yes & 17 & 35.4 & 22 & 45.8 & 39 & 81.3 \\
\hline No & 7 & 14.6 & 2 & 4.2 & 9 & 18.8 \\
\hline \multicolumn{7}{|l|}{ Adverse effects in previous G-CSF usage } \\
\hline None & 8 & 16.7 & 2 & 4.2 & 4 & 20.9 \\
\hline Bodily pain & 16 & 33.3 & 22 & 45.8 & 44 & 79.1 \\
\hline Methods of coping with previous pain & & & & & & \\
\hline Analgesic medications & 15 & 31.3 & 9 & 18.8 & 24 & 50.4 \\
\hline Relaxation techniques & 1 & 2.1 & 0 & 0 & 1 & 2.1 \\
\hline Massage & 0 & 0 & 1 & 2.1 & 1 & 2.1 \\
\hline $\begin{array}{l}\text { Other (analgesics, relaxation } \\
\text { techniques, massage, resting) }\end{array}$ & 0 & 0 & 13 & 27.1 & 13 & 27.1 \\
\hline Nothing & 8 & 16.7 & 1 & 2.1 & 9 & 18.8 \\
\hline
\end{tabular}

\section{Effectiveness of administration time of filgrastim in pain}

Previous filgrastim was reported to cause diffuse bodily pain in $79.1 \%$. Of these patients, $50.4 \%$ used analgesic medication, $27.1 \%$ used analgesics, relaxation techniques, massage, and resting for pain management while $18.8 \%$ used no intervention in prior usage of filgrastim (Tab. 2). In group A, the pain score in the first stage (filgrastim administered at 10: 00) was significantly higher compared to filgrastim administered at $14: 00$ in the second stage (0th hour: $\mathrm{p}=0.020$; 4 th hour: $\mathrm{p}=0.01 ; 8$ th hour: $\mathrm{p}<0.001$; 12 th hour: $\mathrm{p}<0.012$ ) (Tab. 3). On the other hand, in group B patients, the pain score in the first stage (filgrastim administered at 14: 00 p.m.) was significantly lower than that in the second stage (fil- 
Tab. 3. Pain scores by the administration time of G-CSF. Wilcoxon Signed Ranks test.

\begin{tabular}{|c|c|c|c|c|c|c|c|c|c|c|c|c|c|c|c|}
\hline \multirow{4}{*}{$\begin{array}{l}\text { Pain } \\
\text { assessment } \\
\text { time }\end{array}$} & \multirow{4}{*}{$\mathrm{n}$} & \multicolumn{14}{|c|}{ Pain score } \\
\hline & & \multicolumn{7}{|c|}{ A group } & \multicolumn{7}{|c|}{ B group } \\
\hline & & \multicolumn{3}{|c|}{ First stage (10: 00) } & \multicolumn{3}{|c|}{ Second stage (14: 00) } & \multirow[b]{2}{*}{$\mathrm{p}$} & \multicolumn{3}{|c|}{ First stage (14: 00) } & \multicolumn{3}{|c|}{ Second stage (10: 00) } & \multirow{2}{*}{$\mathrm{p}$} \\
\hline & & $25 \%$ & Median & $75 \%$ & $25 \%$ & Median & $75 \%$ & & $25 \%$ & Median & $75 \%$ & $25 \%$ & Median & $75 \%$ & \\
\hline $0^{\text {th }}$ hour & 24 & 0 & 0 & 1 & 0 & 0 & 0 & 0.020 & 0 & 0 & 0 & 0 & 0 & 0 & 0.564 \\
\hline $4^{\text {th }}$ hour & 24 & 1 & 2 & 3 & 1 & 1 & 2 & 0.01 & 1 & 1 & 2 & 1 & 2 & 2 & 0.016 \\
\hline $8^{\text {th }}$ hour & 24 & 2 & 2.5 & 4 & 1 & 1 & 1.75 & 0.001 & 1 & 1 & 2 & 1 & 2 & 2.75 & 0.027 \\
\hline $12^{\text {th }}$ hour & 24 & 1 & 1 & 2 & 1 & 1 & 1 & 0.012 & 0 & 1 & 1 & 1 & 1 & 2 & 0.012 \\
\hline
\end{tabular}

Tab. 4. G-CSF administration time-related pain scores by informative characteristics of patients.

\begin{tabular}{|c|c|c|c|c|c|c|c|c|c|c|c|c|c|c|c|c|c|c|}
\hline \multirow{2}{*}{\multicolumn{3}{|c|}{ Informative characteristics }} & \multicolumn{16}{|c|}{ Pain score } \\
\hline & & & \multicolumn{4}{|c|}{$0^{\text {th }}$ hour } & \multicolumn{4}{|c|}{$4^{\text {th }}$ hour } & \multicolumn{4}{|c|}{$8^{\text {th }}$ hour } & \multicolumn{4}{|c|}{$12^{\text {th }}$ hour } \\
\hline Group & Gender & $\mathrm{n}$ & $25 \%$ & Median & $75 \%$ & $\mathrm{p}$ & $25 \%$ & Median & $75 \%$ & $\mathrm{p}$ & $25 \%$ & Median & $75 \%$ & $\mathrm{p}$ & $25 \%$ & Median & $75 \%$ & $\mathrm{p}$ \\
\hline \multirow{2}{*}{ A } & Female & 11 & 0 & 0 & 1 & \multirow[b]{2}{*}{$0.384 *$} & 1 & 2 & 3 & \multirow[b]{2}{*}{$0.965 *$} & 2 & 2.5 & 4 & \multirow[b]{2}{*}{$0.079 *$} & 1 & 1 & 2 & \multirow{2}{*}{$0.071 *$} \\
\hline & Male & 13 & 0 & 0 & 0 & & 1 & 1 & 2 & & 1 & 1 & 2 & & 0 & 1 & 1 & \\
\hline \multirow{2}{*}{ B } & Female & 15 & 0 & 0 & 0 & \multirow{2}{*}{$0.905^{*}$} & 1 & 1 & 2 & \multirow{2}{*}{$0.552 *$} & 1 & 1 & 1.75 & \multirow{2}{*}{$0.888 *$} & 1 & 1 & 1 & \multirow{2}{*}{$0.863^{*}$} \\
\hline & Male & 9 & 0 & 0 & 0 & & 1 & 2 & 2 & & 1 & 2 & 2.75 & & 1 & 1 & 2 & \\
\hline \multirow[b]{2}{*}{ A } & Married & 22 & 0 & 0 & 0 & \multirow{2}{*}{$0.960 *$} & 1 & 2 & 2 & \multirow{2}{*}{$0.531^{*}$} & 1 & 2 & 3 & \multirow{2}{*}{$0.128 *$} & 1 & 1 & 1 & \multirow{2}{*}{$0.052 *$} \\
\hline & Single & 2 & 0 & 0 & 0.5 & & 1 & 1 & 1 & & 0.5 & 1 & 2 & & 0 & 0 & 0 & \\
\hline \multirow{3}{*}{ B } & Married & 21 & 0 & 0 & 0 & \multirow{2}{*}{$0.626^{*}$} & 1 & 2 & 2 & \multirow{2}{*}{$0.093 *$} & 1 & 1 & 2 & \multirow{2}{*}{$0.864 *$} & 1 & 1 & 2 & \multirow{2}{*}{$0.137^{*}$} \\
\hline & Single & 3 & 0 & 0 & 0 & & 0.5 & 1 & 1.5 & & 1 & 1 & 2.5 & & 0 & 1 & 1 & \\
\hline & Educational st & atus & & & & & & & & & & & & & & & & \\
\hline & Literate & 6 & 0 & 0 & 1 & & 1 & 2 & 3.75 & & 2 & 3 & 4.75 & & 1 & 1.5 & 2 & \\
\hline A & $\begin{array}{l}\text { Secondary } \\
\text { school }\end{array}$ & 9 & 0 & 0 & 0 & $0.34 * *$ & 1 & 2 & 3 & $0.075^{* *}$ & 1 & 2 & 3 & $0.044 * *$ & 0 & 1 & 1 & $0.050^{* *}$ \\
\hline & High school & 5 & 0 & 0 & 0 & & 1 & 1 & 2 & & 1 & 1 & 2 & & 0 & 1 & 1 & \\
\hline & Literate & 2 & 0 & 0 & 0 & & 1 & 2 & 2 & & 1 & 2 & 2.75 & & 1 & 1 & 2 & \\
\hline & Primary schoo & & 0 & 0 & 0 & & 1 & 1.5 & 2 & & 1 & 1 & 2.75 & & 0 & 0.5 & 1.75 & \\
\hline B & $\begin{array}{l}\text { Secondary } \\
\text { school }\end{array}$ & 11 & 0 & 0 & 0 & $0.41 * *$ & 1 & 2 & 2 & $0.34 * *$ & 1 & 1 & 2 & $0.21 * *$ & 1 & 1 & 2 & $0.61 * *$ \\
\hline & High school & 7 & 0 & 0 & 0 & & 1 & 1 & 2 & & 1 & 1 & 1 & & 0.25 & 1 & 1 & \\
\hline & Previous use & $f \mathrm{G}-\mathrm{C}$ & & & & & & & & & & & & & & & & \\
\hline$A$ & Yes & 17 & 0 & 0 & 0 & 0 508* & 1 & 1 & 2 & $0203 *$ & 1 & 1 & 1 & $0228 *$ & 0 & 0 & 0 & $0827 *$ \\
\hline A & No & 7 & 0 & 0 & 0 & $0.508^{*}$ & 1 & 2 & 3 & 0.203 & 0 & 1 & 1 & 0.220 & 0 & 0 & 0 & 0.821 \\
\hline & Yes & 22 & 0 & 0 & 0 & & 1 & 2 & 2 & & 1 & 1 & 2 & & 1 & 1 & 1 & \\
\hline B & No & 2 & 0 & 0 & 0 & $0.815^{*}$ & 1 & 1 & 1.5 & 0.14 & 1 & 1 & 1 & $0.114^{*}$ & 1 & 1 & 2 & \\
\hline
\end{tabular}

*Mann-Whitney U test; **Independent Samples Kruskal-Wallis test

grastim administered at 10: 00; 0th hour: $\mathrm{p}=0.564$; 4th hour: $\mathrm{p}=$ 0.016; 8th hour: $\mathrm{p}=0.027$; 12th hour: $\mathrm{p}=0.012$ ) (Tab. 3).

Socio-demographic characteristics of effectiveness of administration time of filgrastim relative to pain

There was no significant relation between pain severity scored after different filgrastim administration times and gender, marital status, educational status and previous filgrastim administrations $(p>0.059)$ (Tab. 4), while mean pain scores were found to be significantly lower in higher educated subjects compared to solely literate subjects $(\mathrm{p}=0.034)$.

\section{Discussion}

Pain is a well-known complication of G-CSF administration. In the present study, filgrastim was reported to cause diffuse bodily pain in $91.7 \%$, while previous use of filgrastim was reported to cause diffuse bodily pain in $79.1 \%$. The mechanisms of bone pain secondary to G-CSF are not fully known but recent studies have been reported to range from $19 \%$ to $59 \%$. Bone pain develops in patients treated with pegfilgrastim and filgrastim $(2,7,8,11,20$, $21)$. On account of bone pain is a well-known complication of G$\mathrm{CSF}$, pain is treated with drugs $(8,9,11,20,21,22)$. Accordingly, in the study by Ogata et al (2005), G-CSF administration resulted in bone pain in $10 \%$ of patients in whom the pain management included nonsteroidal antiinflammatory drugs (NSAIDs) and hydroxyzine. In the study by Kirshner et al (2012), bone pain associated G-CSF should be treated with naproxen while pain relief in patients managed with hydroxyzine but not in those managed with NSAIDs in the study of Ogata et al $(2005)(11,21)$. According to Carr (2012), mild bone pain induced by G-CSF should be treated with paracetamol but the number of G-CSF administration days and/or G-CSF dose should be changed in the case of intoler- 
able severe pain (9). Some works also reported that patients were treated with loratadine $(8,20)$. It has been emphasized that paying attention to circadian rhythm with determination of the dose and administration time of the drug is essential for the best pharmacokinetic results of the drugs $(23,24)$. It has been also suggested to the drug administrating health professionals to consider the factors that are associated with the pharmacokinetic features of the drug, such as the activity and resting periods of the patient, posture, meal times and meal contents, and galenic formulations particularly when using the drugs with a narrow therapeutic window (25). However, literature search revealed no studies assessing the relationship between G-CSF administration time and pain level. Authors of this study planned the present a study with the hypothesis that G-CSF administration time affects the level of G-CSF-associated pain and found that the pain was statistically significantly lower when G-CSF was administered at 14: 00 compared to administration at 10:00

In the study by Mendez-Ferrer et al (2008), circulation of hematopoietic stem cells has been reported to peak 5 hours after sunrise, decrease 5 hours after sunset and circulate during the day (26). The authors have also suggested that activation of the nervous system also changes in relation to these circadian rhythms. Saba et al (2013) have also reported similar findings (27). In studies examining the effects of circadian ryhtm and exercise on homeostasis, exercise was found to influence platelet synthesis (28, 29) with increased platelet synthesis during daylight (29). MoraRodriguez and Coyle (2000) have reported significantly increased plasma norepinephrine level with exercise (30) with another study reporting that G-CSF and adrenergic signal collaborate to trigger the output of hematopoietic stem cells to the peripheral area (31). In our study, it has been considered that the reason of lower pain level with G-CSF administered at 14: 00 p.m. may be associated with the effect of circadian ryhtm and exercise via increasing the concentration of hematopoietic stem cells in daytime $(26,28,29$, 31 ) and that with G-CSF administered at 10: 00, pain level might increase 4 and 8 hours after injection because of overstimulation of bone marrow. Accordingly, the decreased hematopopietic stem cell circulation after sunset (26) may be associated with lower pain level assessed 4 and 8 hours after G-CSF administration at 14: 00 p.m.

\section{Conclusion}

It was determined in the present study that in order to minimize the pain, it will be more beneficial to administer G-CSF at 14: 00 . This should be of importance in the nursing practice aimed at pain reduction and sustenance of the quality of life of patients, thus enabling uninterrupted treatment.

\section{References}

1. National Comprehensive Cancer Network Clinical Practice Guidelines in Oncology. Myeloid growth factors, version 1.2015. www.ncen. org/professionals/physician_gls/pdf/myeloid_growth.pdf. Accessed 10 September 2015.
2. Leung M, Florendo J, Kano J, Marr-Del Monte T, Higgins B, Myers R, Menon T, Jones G. A modified filgrastim regimen does not reduce pain burden compared to pegfilgrastim in women receiving chemotherapy for non-metastatic breast cancer. Support Care Cancer 2015; Jun; 23 (6): 1669-1677.

3. Lambertini M, Mastro LD, Bellodi A et al. The five "Ws" for bone pain due to the administration of granulocyte-colony stimulating factors. Crit Rev Oncol Hematol 2013; 1782: 16-33.

4. White N, Maxwell C, Michelson J et al. Protocols for managing chemotherapy induced neutropenia in clinical oncology practices. Cancer Nurs 2005; 28 (1): 62-70.

5. Bendall LJ, Bradstock KF. G-CSF: From granulopoietic stimulant to bone marrow stem cell mobilizing agent. Cytokine Growth Factor Rev 2014; 25: 355-367.

6. Uz B, Göker H, Büyükaşık Y et al. Comparison of filgrastim and lenograstim on mobilization of peripheral blood stem cells in healthy donors. Yeni Tip Dergisi 2013; 30 (1): 42-45.

7. Gavioli E, Abrams M. Prevention of granulocyte-colony stimulating factor (G-CSF) induced bone pain using double histamine blockade. Support Care Cancer 2017; 25 (3): 817-822.

8. Pawloski PA, Larsen M, Thoresen A et al. Pegfilgrastim use and bone pain: A cohort study of community-based cancer patients. J Oncol Pharm Practice 2015. doi: 10.1177/1078155215585188.

9. Carr J. Guideline for the Use of Granulocyte-Colony Stimulating Factor (G-CSF) in Adult Patients. Avon, Somerset and Wiltshire Cancer Services 2012. www.avon.nhs.uk/aswcschemo/NetworkPolicies/ASWCS $\% 20$ GCSF\%20policy_Final_120126.pdf. Accessed 10 November 2014.

10. Aldairy Y, Nguyen PL, Jatoi A. Bone pain from granulocyte colonystimulating factor: does clinical trial sponsorship by a pharmaceuticalcompany influence its reporting? Eur J Cancer Care 2011; 20: 72-76.

11. Ogata S, Ito K, Kadoike $\mathbf{K}$ et al. The incidence of bone pain with granulocyte colony stimulating factor (G-CSF) administration and the effect of hydroxyzine. J Clin Oncol 2005; 23 (Suppl 1): 8242.

12. Junker U, Wirz S. Chronobiology: influence of circadian rhythms on the therapy of severe pain. J Oncol Pharm Pract 2010; 16: 81-87.

13. Bellamy N, Sothern RB, Campbell J. Aspects of diurnal rhythmicity in pain, stiffness, and fatigue in patients with fibromyalgia. J Rheumatol 2004; 31 (2): 379-389.

14. Smaaland R, Laerum OD, Sothern RB et al. Colony-forming unit-granulocyte-macrophage and dna synthesis of human bone marrow are circadian stage-dependent and show covariation. Blood 1992; 9 (1): 2281-2287.

15. Smaaland R, Sothern RB, Laerum OD et al. Rhythms in human bone marrow and blood cells. Chronobiol Int Jan 2002; 19 (1): 101-127.

16. Kuderer NM, Dale DC, Crawford J et al. Impact of primary prophylaxis with granulocyte colony-stimulating factor on febril neutropenia and mortality in adult cancer patients receiving chemotherapy: A systematic review. J Clin Oncol 2007; 25 (21): 3158-3167.

17. Dolan S, Crombez P, Munoz M. Neutropenia management with granulocyte colony-stimulating factors: From guidelines to nursing practice protocols. Eur J Oncol Nurs 2005; 9: 14-23.

18. Aslan FE. Pain assessment methods. Cumhuriyet Univ J Nurs 2002; 6(1): 9-16.

19. IBM Corp. Released. IBM SPSS statistics for windows, version 21.0. Armonk, NY: IBM Corporation. 2012. 


\section{9-404}

20. Romeo C, Li Q, Copeland L. Severe pegfilgrastim-induced bone pain completely alleviated with loratadine: A case report. J Oncol Pharm Pract 2015; 21 (4): 301-304.

21. Kirshner JJ, Heckler CE, Janelsins MC, Dakhil SR, Hopkins JO, Coles C, Morrow GR. Prevention of pegfilgrastim-induced bone pain: A phase III double-blind placebo-controlled randomized clinical trial of the university of Rochester Cancer Center clinical community oncology program research base. J Clin Oncol 2012; 30 (16): 1974-1980.

22. D'Souza A, Jaiyesimi I, Trainor $\mathbf{L}$ et al. Granulocyte colony-stimulating factor administration: Adverse events. Transfus Med Rev 2008; 22 (4): $280-290$

23. Reinberg AE. Concepts in chronopharmacology. Annual Rev Pharmacol Toxicol 1992; 32: 51-66.

24. Baraldo M. The influence of circadian rhythms on the kinetics of drugs in humans. Exp Opinion Drug Metab Toxicol 2008; 4 (2): 175-192.

25. Erkekoğlu P, Baydar T. Chronopharmacokinetics of drugs in toxicological aspects: A short review for pharmacy practitioners. J Res Pharm Pract 2012; 1 (1): 3-9.
26. Méndez-Ferrer S, Lucas D, Battista M et al. Haematopoietic stem cell release is regulated by circadian oscillations. Nature 2008. doi: 10.1038 /nature 06685 .

27. Saba F, Soleimani M, Atashi A et al. The role of the nervous system in hematopoietic stem cell mobilization. Lab Hematol 2013; 19: 8-16.

28. Mahmoodinezhad S, Ahakerian S, Ghalavand A, Motamedi P, Mojtaba $\mathbf{D}$. The effect of acute training and circadian rhythm on blood hemostasis in female athletes. Int J Basic Sci Med 2016; 1 (1): 8-12.

29. Ribeiro J, Almeida-Dias A, Ascnsao, Magalhaes J, Oliveira AR, Carlson J, Mota J, Appell HJ, Duarte J. Hemostatic response to acute physical exercise in healthy adolescents. J Sci Med Sport 2007; 10: 164169.

30. Mora-Rodriguez R, Edward FC. Effects of plasma epinephrine on fat metabolism during exercise: interactions with exercise intensity. Am J Physiol Endocrinol Metab 2000; 278; 669-677.

31. Katayama Y, Battista M, Kao W, Hidalgo A, Peired AJ, Thomas SA, Frenette PS. Signals from the sympathetic nervous system regulate hematopoietic stem cell egress from bone marrow. Cell 2006; 124: 407-421

Received January 28, 2017. Accepted March 1, 2017. 